\title{
THE EFFECTIVENESS OF PNPM-SPP PROGRAM ON SOCIETY WELFARE: ISLAMIC ECONOMIC PERSPECTIVE
}

\author{
Tesa Mellina \\ Postgraduate Program, Universitas Darussalam Gontor, East Java, \\ Indonesia, Jl. Raya Siman Km. 6, Siman, Dusun I, Demangan, Ponorogo \\ District, Ponorogo Regency, East Java 63471 \\ Email: tesa.eca31@gmail.com \\ Mohammad Ghozali \\ Postgraduate Program, Universitas Darussalam Gontor, East Java, \\ Indonesia, Jl. Raya Siman Km. 6, Siman, Dusun I, Demangan, Ponorogo \\ District, Ponorogo Regency, East Java 63471 \\ Email: mohammadghozali@ unida.gontor.ac.id
}

\begin{abstract}
Economic activities in rural areas are still dominated by micro business sectors. The majority of business agents are women who are always constrained by capital in economic activities. Though capital is one of the most important elements in moving the economy in a rural area. Limited capital can prevent creativity in business development. Looking at the facts, people should be able to get capital easily. Program Nasional Pemberdayaan Masyarakat is a national integrated poverty reduction program and is a community empowerment program launched by the government. PNPM in one of its programs facilitates the community in Obtaining additional capital by providing a capital loan for women who have a business, namely Simpan Pinjam Perempuan (SPP) program. This study aims to determine the effectiveness of Simpan Pinjam Perempuan (SPP) program and the Islamic economic perspective of the SPP program in an effort to prosper the Cantuk Banyuwangi community. The variables used to measure the effectiveness of the SPP program are the variables of achieving goals, integration, real change, and satisfaction. Program effectiveness is the dependent variable. The study was conducted on 80 SPP lenders. The selection of respondents was by Sampling Cluster method. As for the data processing, the data was done by quantitative statistical analysis method and used a qualitative descriptive method for analyzing qualitative analysis data. Based on the research, the results showed that the effectiveness of the SPP program in Cantuk Banyuwangi Village was very effective with a percentage of $93.3 \%$.
\end{abstract}

Keywords: SPP Program; Effectiveness; Welfare

How to Cite: Mellina, T., \& Ghozali, M. (2019). The Effectiveness Of PNPM-SPP Program On Society Welfare: Islamic Economic Perspective. Jurnal Ilmiah Al-Syir'ah, 17(1), 77-90.

Permalink/DOI: http://dx.doi.org/10.30984/jis.v17i1. 641

Copyright @ 2019, Jurnal Ilmiah Al-Syir'ah 


\section{INTRODUCTION}

Generally, the majority of rural people are poor and far from prosperous category. Rural economic activity is still dominated by micro business sectors such as trade and agriculture. Most entrepreneurs are women who conduct their economic activities constrained by capital become one of the most important elements in the economy. One of the effects of capital constraints is inhibiting the development of microenterprises of rural communities (Ana, 2015: 2).

The empowerment program launched by the government in poverty alleviation integrated and sustainable is Program Nasional Pemberdayaan Masyarakat (Damian, 2014: 2). One of the goals is to facilitate the financing of micro-enterprises, such as Simpan Pinjam Perempuan. In addition, it is to strengthen the institutional activities of women and to encourage the reduction of Poor Households and job vacancy in rural areas. (Shella and Zaili, 2012: 2).

In Islam, decreasing the gap between rich and poor is becoming a necessity. It is to realize the balance and prevent social inequality. Thus, it is the duty of every Muslim to help each other. Allah says in Surah AlHashr:59 as follows: "And what Allah restored to His Messenger from the people of the towns - it is for Allah and for the Messenger and for [his] near relatives and orphans and the [stranded] traveler - so that it will not be a perpetual distribution among the rich from among you. And whatever the Messenger has given you - take; and what he has forbidden you - refrain from. And fear Allah; indeed, Allah is severe in penalty ". (Q.S. Surah alHashr: 7).

The word of Allah SWT explains the importance of the distribution of wealth in running the economy. Wealth should be shared to the whole society, hence it is not only for the rich. By the evidence of the poor inability in terms of capital, every Muslim must help each other, as the word of Allah SWT in the Qur'an Surah Al-Maidah paragraph 2 as follows: "And cooperate in righteousness and piety, but do not cooperate in sin and aggression. And fear Allah; indeed, Allah is severe in penalty ". (QS. AlMai'dah: 2)

The existence of PNPM-SPP is one way to solve the problems of poverty and social inequality. Provision of venture capital for the community is a form of government concern to the community. Capital lending system of micro-enterprise is expected that people can live in prosperity. One of the areas applying PNPM-SPP is Cantuk Village, Singojuruh District, Banyuwangi Regency. By the implementation of the program, the government of Cantuk Village hopes that it can support the success of the economic activity and create public welfare of Cantuk Village, however, the implementation may have an obstacle.

In general, the major problems of the program is a discrepancy between the implementation of the program with the Technical Operational Guidelines. Surely discrepancies in the implementation of the program have 
an impact on the original purpose of the implementation of the program because the creation of economic success and prosperity depend on the effective implementation of a program implemented correctly according to the technical operations. According to this background, this study is aimed to examine how the effectiveness of the SPP program in Cantuk Banyuwangi Village and Islamic Economic study of the SPP program for the welfare of society.

\section{RESEARCH METHODS}

The study was conducted in Cantuk Village, Singojuruh District, Banyuwangi Regency. In using a combination of embedded concurrent models, quantitative method is as the primary method and qualitative method is as a secondary method. The variables used to measure the effectiveness of the SPP program is to achieve goals, integration, real change and satisfaction. The object of research is in the village of SPP program in Cantuk Banyuwangi Village. The research conducted on 80 respondents who are members of society as SPP lenders by using Cluster Sampling method. In processing the data, the validity test used SPSS 17, while the data reliability test used Cronbach alpha reliability. To analyze the data is by using statistic analysis method for quantitative data with effectiveness ratio criteria table and descriptive qualitative analysis method for qualitative data.

\section{RESULTS AND DISCUSSION}

\section{ORGANIZATION EFFECTIVENESS CONCEPT}

In any organization, effectiveness is an integral part of the goals or objectives achievement that had been determined. In other words, activity is effective if the objectives or targets are achieved, on the contrary, if the goals are not achieved in accordance with the original purpose of the activity, the program is not effective (Iga, 2012: 3).

Briefly, the definition of effectiveness has a different meaning for each person, depending on the terms of reference uses (Richard, 1985: 1). Thus, it can be interpreted that effectiveness is the achievement of the objectives to be reached immediately, so these objectives can be implemented as the expectations.

In this study, some indicators used is an indicator of the achievement of objectives consisting of timeliness and precision targeting, integration indicators, indicators of change and satisfaction.

\section{Welfare Concept in Islam}

Welfare is a human condition in which people are in a prosperous, healthy and peaceful condition, thus to achieve the conditions require an appropriate business ability (Astriana, 2009: 3). Meanwhile, according to 
Kamus Lengkap Bahasa Indonesia, prosperous means safe, tranquil and prosperous (Windy: 539).

Comparing to conventional welfare concept, the prosperity concept of Islamic Economic is different, as an economist, Pareto stated that in conventional economy, welfare is only to the welfare of the material, because the welfare of nonmaterial (psychic) is not considered the economic field. While Islamic economic concept focuses on nonmaterial in achieving the welfare (Hasan, 2011: 112). Systematically Islamic welfare function is:

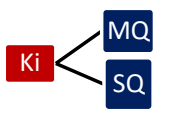

Where:

$$
\begin{array}{ll}
\mathrm{Ki} & \text { : Islamic welfare } \\
\mathrm{MQ} & \text { : Material quotient } \\
\mathrm{SQ} & \text { : Spiritual quotient }
\end{array}
$$

Therefore, the welfare of the Islamic economic perspective is the fulfillment of material and non-material needs (Amirus, 2015: 11-13) in which in fulfilling the needs of both material and non-material is by considering maslahah. Maslahah is a concept that is relevant in the public welfare and in accordance with sharia maqashid. The Islamic welfare index based on maslahah is to measure welfare by five dimensions, as Imam AlGhazali thought, such as the dimension of religion (al-diin), the dimensions of the soul (an-nafs), the dimensions of reason (al-'aql), the dimensions of offspring (al-nasl), and the dimensions of the property (al-maal). Therefore, the Islamic economy does not ignore the material need as long as it is legal and used as the guidance of Allah SWT.

The welfare indicators which are in Al Qur'an, as follows: Full dependence of man to God. Man's dependence on God is by worship as the main indicator of well-being; Loss of hunger (the requirement for consumption). In the Islamic economy, the fulfillment of human consumption which is one indicator of well-being should be adequate and not excessive especially for hoarding; Absence of fear. The loss of fear is a representation of achieving safety, comfort, and peace.

\section{PNPM-SPP}

In 2007, the Indonesian government started to launch Program Nasional Pemberdayaan Masyarakat Mandiri consisting of PNPM Mandiri of rural areas, PNPM Mandiri of urban areas, and PNPM Mandiri of special areas and villages. PNPM is a program to accelerate poverty reduction and sustainable integrated manner. PNPM is the development of the District Development Program which was considered successful and has been conducted since 1998. The PNPM itself confirmed officially by the President on April 30th, 2007 in Palu, Central Sulawesi (Damian, 2014: 2).

In the implementation of Program Nasional Pemberdayaan Masyarakat Mandiri in Rural Areas (PNPM-MP) basically consists of four aspects, namely Development of Physical Infrastructure, Development of Health Care and Education and Capacity Building or Skills Society and 
Women's Credit, (Shella and Zaili, 2012: 2). The discussion of Simpan Pinjam Perempuan (SPP) is the primary object of research.

Simpan Pinjam Perempuan (SPP) activities are functioned to provide capital for women who have saving and loan activities. In general, this activity aims to: Develop the potential of rural micro-credit activities; Ease of access to finance micro-enterprises; Fulfillment of basic social funding; Strengthen women's activities institution; Encourage prevention of Poor Households and job vacancy in rural areas (Damian, 2014: 11).

The form of SPP activity is to provide loan funds for additional working capital for the group of women who have a productive business. (Ana, 2015: 4)

\section{DESCRIPTION OF LOCATION}

Cantuk village is one of the villages in Singojuruh District, Banyuwangi Regency. Cantuk village has an extensive area of 313,18 ha / $\mathrm{m} 2$. This village is divided into four hamlets, South Cantuk, North Cantuk, Rampan, and Kelampokan. Most of the population is Muslim, while the other 6 religions are Christian from the population about 4,362 people consisting of 2,051 men and 2,311 women. Most of them are farm laborers or 1060 people. While others are entrepreneurs, traders, tailors, border businesses and farmers.

\section{General Characteristics of Respondents}

\section{Based on Age Criteria}

\section{Figure 1}

\section{RESPONDENT GRAPH BASED ON AGE}

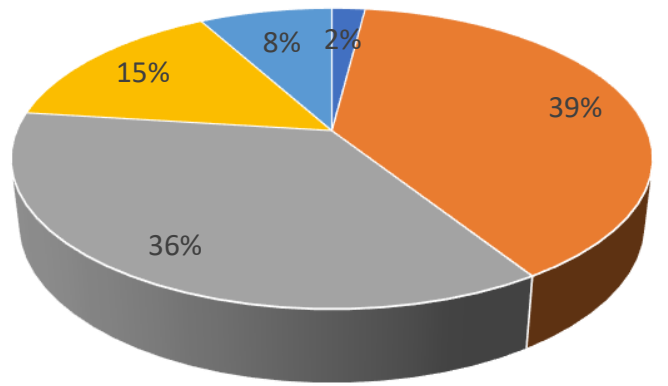

- Age 20-30 - Age 31-40 -Age 41-50 - Age 51-60 - Age 61-70

Sources: Primary data, in 2016 
Jurnal Ilmiah Al-Syir'ah Vol. 17, No. 1 (2019): 77-90

Website: http://journal.iain-manado.ac.id/index.php/JIS

ISSN 2528-0368 (online) ISSN 1693-4202 (print)

82

From the explanation, it was obtained more than 50\% of SPP beneficiaries in Cantuk village belong to the productive age who are physically capable of running the business and being able to think to expand business through the capital raised.

\section{Based on Educational Level}

\section{Figure 2}

\section{RESPONDENT GRAPH BASED ON EDUCATIONAL} LEVEL

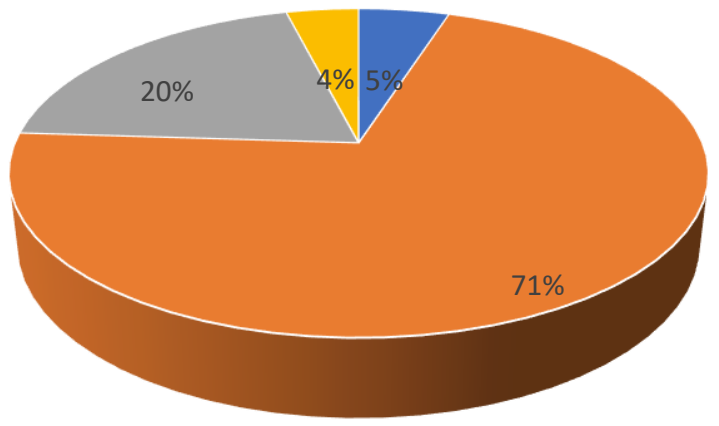

- No School - Elementary School - Junior High School - Senior Hight School

Sources: Primary data, in 2016

Based on Business Type

Figure 3

\section{RESPONDENT CHARACTERISTIC BASED ON BUSINESS TYPE}

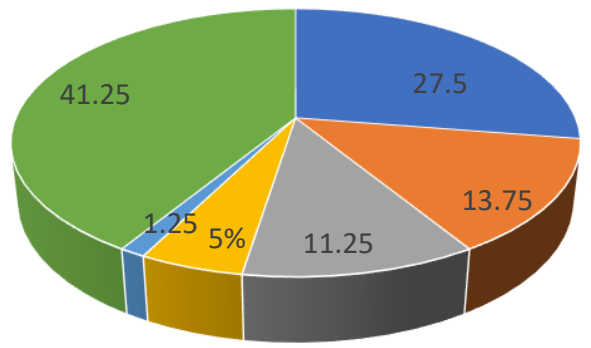

- Border Businesses " Farm Laborers " Farmers - Entrepreneurs " Tailors " Traders

Sources: Primary data, in 2016 
Based on the table above, it cannot be found respondents who do not have a business. This means that the respondents' SPP funds used for the benefit of developing a productive business that has been run previously. Moreover, the data proved that the SPP program has been targeted appropriately for SPP funds are distributed and according to the procedure, that is for women who have a productive business. (Ana, 2015: 4).

\section{VALIDITY TEST}

Table 1

The results of Validity Test

\begin{tabular}{ccccc}
\hline No. & Instrument & R count & R table & validity \\
\hline 1 & Question 1 & .936 & 0.286 & valid \\
2 & Question 2 & 0.884 & 0.286 & valid \\
3 & Question 3 & .769 & 0.286 & valid \\
4 & Question 4 & 0.876 & 0.286 & valid \\
5 & Question 5 & 0.899 & 0.286 & valid \\
6 & Question 6 & 0.618 & 0.286 & valid \\
7 & Question 7 & 0.883 & 0.286 & valid \\
8 & Question 8 & .783 & 0.286 & valid \\
9 & Question 9 & 0.876 & 0.286 & valid \\
10 & Question 10 & 0.908 & 0.286 & valid \\
11 & Question 11 & .670 & 0.286 & valid \\
12 & Question 12 & .936 & 0.286 & valid \\
13 & Question 13 & 0.666 & 0.286 & valid \\
14 & Question 14 & 0.889 & 0.286 & valid \\
\hline
\end{tabular}

Source: Analysis of primary data, 2016

Based on the results of data analysis using SPSS statistics 17 stated that the research instruments used by researcher are valid, in which $r_{\text {count }} \geq r_{\text {table }}$ so the whole instrument can be used as a measuring tool in this study.

RELIABILITY TEST

Table 2

Reliability Test Results

\begin{tabular}{ccccc}
\hline No. & $\begin{array}{c}\text { Measuring } \\
\text { instrument }\end{array}$ & Cronbach's Alpha & Criteria & Status \\
\hline 1 & Effectiveness & 0.909 & $\geq 0,60$ & reliable \\
\hline \multicolumn{4}{r}{ Source: Analysis of primary data, 2016 } \\
\end{tabular}

Based on table 1 of reliability test has shown good results for the coefficient of Cronbach's Alpha produced has been qualified, that is $>0.60$, which means that the measuring instrument used in this study has the feasibility and been considered reliable to be used as a measurement variable. 
SPP PROGRAM EFFECTIVENESS IN CANTUK BANYUWANGI VILLAGE

Based on the research results, the effective implementation of SPP program with goal achievement indicators consists of punctuality and precision targeting, integration, real change and satisfaction, the level of effectiveness of the SPP program in Cantuk Banyuwangi village are as follows:

\section{Indicators 1. Goal Achievement}

On this indicator, there are two questions: timeliness in the disbursement of funds by SPP officers to the community and the timeliness of the refund by the public to the officer of SPP. Relevant research of SPP program goal achievement indicators can be seen in the following table:

Table 3

Effectiveness Score of Achievement Indicators

\begin{tabular}{cccc}
\hline No. & Question & Respondents & Percentage \\
\hline 1. & SPP timeliness of funds disbursement & 374 & $93.5 \%$ \\
2. & Timeliness of repayment & 398 & $99.5 \%$ \\
& Total & $\mathbf{3 8 6}$ & $\mathbf{9 6 . 5 \%}$ \\
\hline
\end{tabular}

Sources: Primary data, 2016

According to the above calculation, it can be seen that all target of goal achievement indicators is $100 \%$ however, the realization obtained is 81 , $2 \%$. From the results of these calculations can be seen that the indicators of goal achievement of SPP program in Cantuk Banyuwangi village classified as very effective, because the total score reached above $80 \%$ and categorized as "very effective".

\section{Indicators 2. Integration}

On this indicator, there are three questions: the level of public awareness towards the existence of SPP program, people's understanding to the purpose of SPP program and how the level of socialization officers, either directly or indirectly to the public. Based on the results of research conducted by researchers related to variable integration of SPP program can be seen in the following table: 
Table 4

\section{Integration Indicators Effectiveness Score}

\begin{tabular}{clccc}
\hline No. & \multicolumn{1}{c}{ Questions } & Respondents & Percentage \\
\hline 1. & $\begin{array}{l}\text { Having known the existence of the SPP } \\
\text { program }\end{array}$ & 380 & $95 \%$ \\
2. & $\begin{array}{l}\text { Understanding the purpose and the use of SPP } \\
\text { well }\end{array}$ & 340 & $85 \%$ \\
3. Socialization officers directly or indirectly & 374 & $93.5 \%$ \\
$\quad$ Total & $\mathbf{3 6 5}$ & $\mathbf{9 1 . 3 \%}$ \\
\hline
\end{tabular}

Sources: Primary data, 2016

According to the above calculation, it can be seen that all target of real change indicators is $100 \%$ and the realization obtained was $91.3 \%$. From the results of these calculations can be seen that the indicators of goal achievement of SPP program in Cantuk Village Banyuwangi classified as very effective because the total score reached above $80 \%$ and categorized as "very effective".

\section{Indicator 3. Real Change}

In real change indicator, there are three questions. Real change is measured from the improvement of economic conditions of society, increasing community income and the existence of SPP programs that can prosper the economy. Based on the results of research conducted by researchers related to real change after variable after the existence of the SPP program can be seen in the following table:

Table 5

Real Change Indicator Effectiveness Score

\begin{tabular}{clcc}
\hline No. & \multicolumn{1}{c}{ Question } & Respondents & Percent \\
\hline 1. & Improvement of economic conditions & 384 & $96 \%$ \\
2. & Increasing income & 372 & $93 \%$ \\
3. & The existence of SPP programs helps & 382 & $95.5 \%$ \\
& the economic prosper & $\mathbf{3 7 9}$ & $\mathbf{9 4 . 8 \%}$ \\
\hline \multicolumn{2}{c}{ Total } & Sources: Primary data, 2016
\end{tabular}

According to the above calculation, it can be seen that all target indicators of real change are $100 \%$ and the realization obtained was $94.8 \%$. From the results of these calculations can be seen that the indicators of goal achievement of SPP program in Cantuk Banyuwangi village classified as very effective, because the total score reached above $80 \%$ and categorized as "very effective". 


\section{Indicators 4. Satisfaction}

Satisfaction indicator consists of three questions, including the suitability of the proposed loan funding by the public, satisfaction of SPP service and politeness and friendliness of SPP's employee's service. Based on the results of research conducted by researchers related to satisfaction variable to the SPP program can be seen in the following table:

Table 6

Satisfaction Indicators Effectiveness Score

\begin{tabular}{clcc}
\hline No. & \multicolumn{1}{c}{ Questions } & Respondents & Percentage \\
\hline 1. & $\begin{array}{l}\text { Provision of the loan in } \\
\text { accordance with the loan } \\
\text { application submitted }\end{array}$ & 340 & $85 \%$ \\
2. $\begin{array}{l}\text { Feeling satisfied with the } \\
\text { services provided by SPP officer }\end{array}$ & 376 & $94 \%$ \\
3. $\begin{array}{l}\text { The politeness and friendliness in } \\
\text { serving the community lenders of } \\
\text { SPP }\end{array}$ & 370 & $92.5 \%$ \\
& & $\mathbf{3 6 2}$ & $\mathbf{9 0 . 5 \%}$ \\
\hline
\end{tabular}

Sources: Primary data, 2016

According to the above calculation, it can be seen that all target indicator is $100 \%$ satisfaction and realization obtained was $90.5 \%$. From the results of these calculations can be seen that the indicators of goal achievement of SPP program in Cantuk Banyuwangi village classified as very effective, because the total score reached above $80 \%$ and categorized as "very effective".

Therefore, the table description of each of the effectiveness indicators above, the SPP program of effectiveness level in community welfare of Cantuk Banyuwangi can be seen in the graph below:

Figure 4

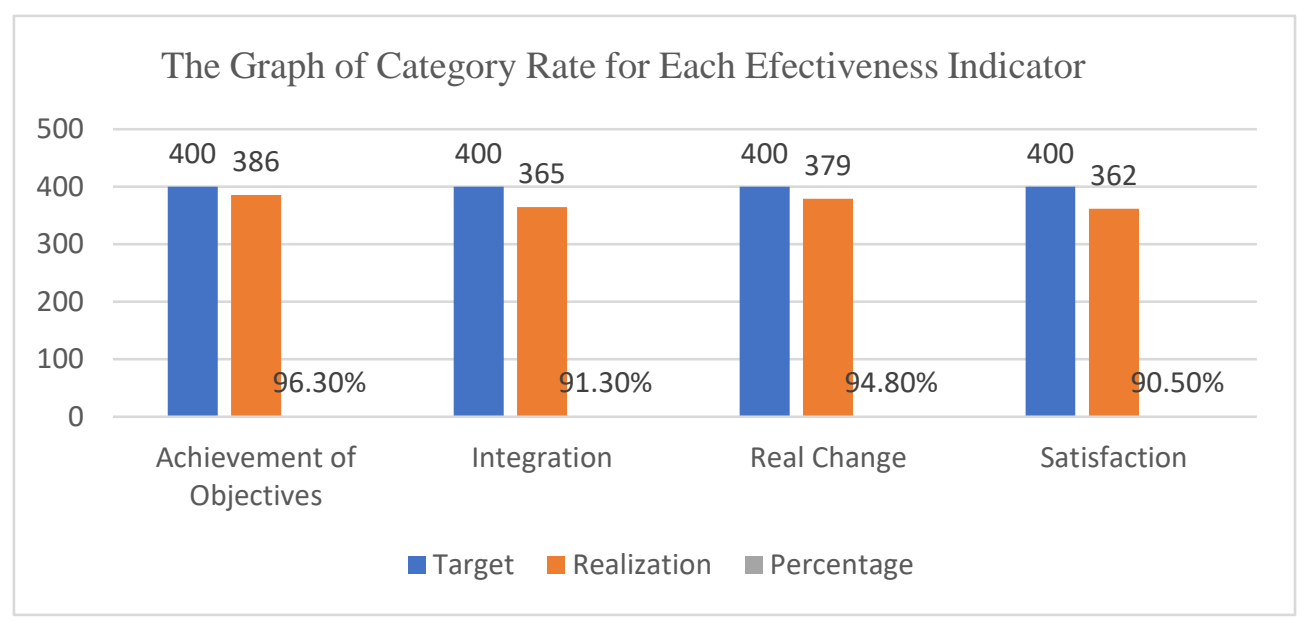

The Effectiveness Of PNPM-SPP Program On Society Welfare: Islamic Economic 
From the graph, it can be concluded that the overall results for the category rate of each sub effectiveness indicator are as follows:

Table 7

Category Rate for Each Sub Effectiveness Indicator

\begin{tabular}{llll}
\hline No. & Sub-indicators & Target & Realization \\
\hline 1. & Achievement of goal & 400 & 386 \\
2. & Integration & 400 & 365 \\
3. & Real change & 400 & 379 \\
4. & Satisfaction & 400 & 362 \\
& Total & $\mathbf{1 , 6 0 0}$ & $\mathbf{1 , 4 9 2}$ \\
\hline
\end{tabular}

Sources: Primary data, 2016

Based on calculations using simple statistics and effectiveness ratio tables obtained, the degree of activity effectiveness was $93.3 \%$ which was classified in "very effective" category in which the granularity was $96.5 \%$ for goal achievement variable, $91.3 \%$ integration variable, $94.8 \%$ for real change variable, and $90.5 \%$ satisfaction variable.

\section{ISLAMIC ECONOMIC PERSPECTIVE ANALYSIS OF SPP PROGRAM INTO THE PUBLIC WELFARE}

From the research conducted, the SPP program has facilitated people feel has to obtain additional capital loan for their economic activities so they have increased the income. SPP program has proven in increasing the public welfare as if it is seen from the public response, there were 67 respondents $(83.75 \%)$ of SPP members who stated that capital needs have been fulfilled after doing SPP program. Like Mrs. Nining Sugiarti statement that SPP program is very helpful in providing capital (Nining, 2017). It can be concluded that people feel comfortable because their needs have been fulfilled.

However, the program implementation has not been relevant to Islamic concept. It has been known that the purpose of the SPP program is to help the community by providing capital loans as a form of government concern. In Islam, it is called by Qardh, in which Qardh loan does not have an interest because the principle in qardh is helping. While according to public statements in the application of the SPP program impose additional charges in the return (interest). Therefore, the program is not in accordance with Islam, because the implementation still applies remuneration has been set in advance. Although the interest is eventually returned to the community through social activities, like the distribution of food, it is not compatible with the concept of Qardh in Islam. 


\section{CONCLUSION}

MSME has a major contribution to the economy in which there are $99.99 \%$ of businesses in Indonesia as MSME. MSME is able to employ labor amounted to $97.02 \%$ and contributes to the Gross Domestic Product (GDP) which is higher than in large enterprises, it is $57.08 \%$. MSME has a higher percentage than the large enterprise, $53.24 \%$ of them from the investment factor. However, MSME still faces financial and non-financial constraints. The main financial problem is the lack of a systematic approach to funding. While the non-financial problem or organizational management is the lack of education and training so the knowledge of technology and marketing is limited. MFI is faced with internal and external constraints in the development of MSME. Institutional aspect is the external constraint faced by MFI that affects in the variety of MFI forms. Internal constraint concerns operational aspects and business empowerment, especially the MFI's ability to the fundraising. KSPPS BMT as one of SMFI is the appropriate institution to develop MSME because KSPPS BMT has Islamic financing methods that give priority to the moral, ethical, and fair so it efficiently can encourage the participation of MSME entrepreneurs to succeed. Moreover, KSPPS BMT has a social fund of zakat to the empowerment of productive business of MSME which is classified as the poor. MSME is financed by KSPPS BMT with various types of financing agreement which can be selected in accordance with the conditions of the MSME when it is considered from the financial side. MSME which is not classified as indigent or poor can access the financing with mudharabah or musyarakah. While MSME considered indigent/poor can obtain financing with qardh or grants. Technical assistance in cooperating with other agencies such as the Department of Cooperatives and Local Government is needed if it is considered from the non-financial side. Training can be the development of marketing skills, technology, business financial records, and so forth. The proposed recommendations based on research results are: 1) KSPPS BMT needs to identify the category of MSME based on their ability to meet the repayment of financing through a survey conducted jointly with local government; 2) KSPPS BMT needs to collaborate with local Zakat Organization for financing program of MSME by qardh and grants agreement; and 3) KSPPS BMT needs to cooperate with the Department of Cooperatives and Local Government to

\section{ACKNOWLEDGMENTS}

The authors express gratitude to the Rector, the Vice Rectors, and all academic members of Gontor Darussalam University who have supported and supervised to complete this article. The next appreciation is expressed to the members of the Editorial Team of Jurnal Ilmiah Al-Syir'ah, Faculty of 
Sharia, State Islamic Institute of Manado who have helped to publish this article.

\section{REFERENCES}

Abbas, K., \& Shirazi, N. (2015). The Key Players' Perception on The Role of Islamic Microfinance in Poverty Alleviation The Case of Pakistan. Journal of Islamic Accounting and Business Research, 6(2) , 244-267.

Adeyemi, A. A., al-Jaafreh, A. S., \& Osman, M. A. (2015). Islamic Microfinance and MSMEs Development in Saudi Arabia : A Qualitative Inquiry. International Journal of Education and Research, 59-72.

Amalia, E. (2009). Keadilan Distributif dalam Ekonomi Islam; Penguatan Peran LKM dan UKM di Indonesia. Jakarta: PT Rajawali Pers.

Anantanyu, S. (2011). Kelembagaan Petani: Peran dan Strategi Pengembangan Kapasitasnya 7(2). SEPA, 7 (2), 102-109.

Antonio, S. (2008). Bank Syariah dari Praktek dan Teori. Jakarta: Gema Insani.

Astuti, R. (2016). Strategi Pengembangan Potensi Usaha Mikro Kecil dan Menengah (UMKM) dengan Dukungan Kucuran Kredit. Industria : Jurnal Teknologi dan Manajemen Agroindustri , 84-95.

Awami, S. N. (2009). Peranan Lembaga Keuangan Mikro dan Kontribusi Kredit terhadap Pendapatan Kotor UKM Rumah Tangga Setelah menjadi Kreditur (Studi Kasus BMT MUAMALAT). MEDIAGRO, 5(2), 1-11.

Aysan, A. F.; Disli, M., Ng. A.; Ozturk, H. (2015). Is small the new big : Islamic banking for SMEs in Turkey. Diambil kembali dari http://doi.org/10.1016/j.econmod.2015.12.031

Azis, A., \& Rusland, A. (2009). Peranan Bank Indonesia di dalam mendukung Pengembangan Usaha Mikro, Kecil, dan Menengah. Dalam B. Indonesia, Seri Kebansentralan (Vol. 21st ed. ). Jakarta: Pusat Pendidikan dan Studi Kebansentralan (PPSK) Bank Indonesia (BI).

Elasrag, H. (t.thn.). Islamic Finance for SMES . Diambil kembali dari http://doi.org/10.1453/jest.v3i3.1009

Huda, A. (2012). The Development of Islamic Financing Scheme for SMEs in a Developing Country : The Indonesian Case. 52, 179-186. http://doi.org/10.1016/j.sbspro.2012.09.454.

Kharisma, B. (2014). Good Governance sebagai Suatu Konsep dan Mengapa Penting dalam Sektor Publik dan Swasta : Suatu Pendekatan Ekonomi Kelembagaan. Jurnal Buletin Studi Ekonomi,, 19(1), 1-34.

Kementerian Perdagangan. (2013). Analisis Peran Lembaga Pembiayaan dalam Pengembangan UMKM. Jakarta: Pusat Kebijakan 
Jurnal Ilmiah Al-Syir'ah Vol. 17, No. 1 (2019): 77-90

Website: http://journal.iain-manado.ac.id/index.php/JIS

ISSN 2528-0368 (online) ISSN 1693-4202 (print)

90

Perdagangan dalam Negeri Badan Pengkajian dan Pengembangan

Kebijakan Perdaganagn Kementerian Perdagangan.

Pristiyanto, Bintoro, M. H., \& Soekarto, S. T. (2015). Strategi

Pengembangan Koperasi Jasa Keuangan Syariah dalam Pembiayaan

Usaha Mikro di Kecamatan Tunjungsari Sumedang. Jurnal Manajemen, 8 (1), 27-35.

Sholahuddin, M. (2013). Tantangan Perbankan Syariah dalam Perananya

Mengembangkan UMKM. Seminar Nasional dan Call for Papers

SANCALL, (hal. 496-500). Surakarta.

Sriyana, J. (2013). Peran BMT dalam Mengatasi Kemiskinan di Kabupaten

Bantul. INFERENSI, Jurnal Penelitian Sosial Keagamaan, 29-50.

Sudarsono, H. (2005). Bank dan Lembaga Keuangan Syariah. Yogyakarta:

Ekonisia.

Sugiyono. (2012). Metode Penelitian Kuantitatif Kualitatif dan R\& D. Bandung: Alfabeta. 